\title{
Synergistic process using Fe hydrolytic flocs and ultrafiltration membrane for enhanced antimony(V) removal
}

\author{
Baiwen Ma ${ }^{\mathrm{a}}$, Xing Wang ${ }^{\mathrm{a}, \mathrm{b}}$, Ruiping Liu ${ }^{\mathrm{a}, *}$, William A. Jefferson ${ }^{\mathrm{a}}$, Huachun Lan ${ }^{\mathrm{a}}$, Huijuan Liu ${ }^{\mathrm{a}}$, \\ Jiuhui $\mathrm{Qu}^{\mathrm{a}}$ \\ a Key Laboratory of Drinking Water Science and Technology, Research Center for Eco-Environmental Sciences, Chinese Academy of Sciences, Beijing 100085, China \\ ${ }^{\mathrm{b}}$ University of Chinese Academy of Sciences, Beijing 100049, China
}

\section{A R T I C L E I N F O}

\section{Keywords:}

In situ Fe hydrolytic flocs

Ultrafiltration membrane

Integrated process

Antimony(V) removal

Fouling properties

\begin{abstract}
A B S T R A C T
Antimony ( $\mathrm{Sb}$ ) is harmful to human health, and $\mathrm{Sb}(\mathrm{V})$ is much more difficult to remove from water than other toxic elements such as arsenic (As). Theoretical studies have suggested that in situ flocs have stronger adsorption ability toward heavy metals than pre-made adsorbents. We believe that rational design of in situ flocs and the associated device structure will enable a floc-based device to be utilized in the removal of heavy metals. Based on this concept, we developed an integrated process taking advantage of the strong adsorption abilities of in-situ $\mathrm{Al}$ or Fe hydrolytic flocs and excellent separation properties of ultrafiltration (UF) membranes. We found that flocs could be well dispersed in a membrane tank with aeration from the bottom, and Fe-based flocs performed better in removing $\mathrm{Sb}(\mathrm{V})$ and alleviating membrane fouling than Al-based flocs. We also demonstrated that higher $\mathrm{Sb}$ (V) removal efficiency was induced with continuous injection, and lower solution $\mathrm{pH}$. By controlling the aeration rate, injection frequency and the solution $\mathrm{pH}$, membrane fouling was alleviated, especially under weakly acidic conditions. Additionally, owing to the higher rejection efficiency of the UF membrane, the effluent quality was improved, including the iron concentration, turbidity, and chromaticity. This innovative separation method shows promising potential for application in removing heavy metals in water treatment.
\end{abstract}

\section{Introduction}

Antimony (Sb), which is similar to arsenic (As), has received great attention due to its high toxicity and carcinogenicity towards humans after long-time exposure [1-3]. The maximum contaminant level (MCL) in drinking water for $\mathrm{Sb}$ is 5.0 and $6.0 \mu \mathrm{g} / \mathrm{L}$ in the USA and Europe, respectively [4,5]. In China, the MCL is $5.0 \mu \mathrm{g} / \mathrm{L}$ [6]. $\mathrm{Sb}(\mathrm{III})$ and $\mathrm{Sb}(\mathrm{V})$ are the two main species, of which $\mathrm{Sb}(\mathrm{III})$ is dominant under anoxic conditions with the main species of $\mathrm{Sb}(\mathrm{OH})_{3}$, while $\mathrm{Sb}(\mathrm{V})$ is dominant in oxic surface waters with the main species of $\mathrm{Sb}(\mathrm{OH})_{6}{ }^{-}$over a wide $\mathrm{pH}$ range $[1,3]$. In comparison with As, the removal of $\mathrm{Sb}$ is much more difficult. Previous study has compared the behaviors between As and Sb during coagulation, and referred to the following order of the removal efficiency for As and $\mathrm{Sb}$ with Fe-based coagulants at neutral $\mathrm{pH}$ condition: $\mathrm{As}(\mathrm{V})>\mathrm{Sb}(\mathrm{III})>\mathrm{As}(\mathrm{III})>\mathrm{Sb}(\mathrm{V})$ [7] .

To remove Sb effectively, various technologies have been investigated, such as coagulation/flocculation [8], membrane separation [9], electrochemical methods [10], adsorption [11], etc. Most studies have found that adsorption is still the most promising method to remove antimony, after considering the cost and practical operation [12-14].
Up to now, many adsorbents have been investigated to remove antimony, such as metal oxides [6,15], sorbents based on waste materials [16], etc. However, the adsorption ability of these aforementioned adsorbents toward Sb is relatively low, and their use in actual operations is inhibited to a large extent by the need for frequent regeneration.

In fact, the synthetic adsorbents always showed reduced adsorption abilities after drying and granulation procedures [1]. To overcome this problem, the freshly prepared adsorbents may be advantageous regarding their adsorption capability due to maintaining the activity of adsorption sites as much as possible. The surface adsorption activity and amorphous structure of the freshly prepared adsorbents can lead to higher affinity for adsorbents. It has been demonstrated that freshly prepared Al hydrolytic flocs significantly improved the removal efficiency of fluoride $(\mathrm{F})$ compared to $\mathrm{AlCl}_{3}$ coagulation, and showed a maximum adsorption ability above $110.0 \mathrm{mg} \mathrm{F} / \mathrm{g}$ Al from $\mathrm{pH}$ 5.0-7.0 [17]. To remove trace concentrations of $\mathrm{Sb}$ in drinking water, $\mathrm{Fe}$ hydrolytic flocs were freshly prepared and the removal efficiency of Sb (V) was significantly increased after filtration. The maximal adsorption capacity of $\mathrm{Sb}(\mathrm{V})$ is as high as $10.2 \mathrm{mM} / \mathrm{g}$ Fe at $\mathrm{pH} 5.0$ [1].

\footnotetext{
* Corresponding author.

E-mail address: liuruiping@rcees.ac.cn (R. Liu).
} 
Although the in situ $\mathrm{Al}$ or $\mathrm{Fe}$ hydrolytic flocs have higher adsorption ability than other adsorbents owing to alleviating the loss of active surface [17], most of these materials are used with a filter bed by loading onto porous carriers during actual operations. Here, a noticeable problem is that the corresponding loading efficiency is always lower due to the properties of the carriers [1]. As a result, the flocs have a large potential to release during filtration, leading to higher concentrations of $\mathrm{Al}$ or $\mathrm{Fe}$ in the effluent. In addition, the in situ $\mathrm{Al}$ or $\mathrm{Fe}$ hydrolytic flocs easily form a cake layer and cannot be fully utilized due to the nature of the flocs. Furthermore, microorganisms would tend to grow after long-time operation, resulting in the need for frequent cleaning and disinfection in the subsequent operations, especially when the influent temperature is high.

It is well known that aluminum salts and iron salts are commonly used coagulants in water treatment, and ultrafiltration (UF) membranes have also been widely applied because of the superior effluent quality achieved, even with variable feed-water properties [18-21]. To overcome the disadvantages mentioned above, we developed an integrated progress based on the strong adsorption ability of in situ flocs and the excellent rejection efficiency of UF membranes. Although previous studies reported that iron salts exhibited strong affinity toward $\mathrm{Sb}$ [22-24], aluminum salts were also investigated in this work after considering the corresponding membrane fouling degree. In this integrated system, flocs were totally suspended in the membrane tank by aeration from the bottom, so that they could be fully utilized. On one hand, the negatively charged $\mathrm{Sb}(\mathrm{V})\left(\mathrm{Sb}(\mathrm{OH})_{6}{ }^{-}\right)$could be easily adsorbed by the freshly prepared flocs, especially under lower $\mathrm{pH}$ conditions with positively charged surface. On the other hand, the flocs could be well separated from the solution by the UF membrane. Furthermore, although the UF membrane pore diameter is relatively large (from several nanometers to dozens of nanometers), it can also remove heavy metals partially due to adsorption by the membrane pores [9], leading to an increase in the $\mathrm{Sb}(\mathrm{V})$ removal efficiency.

To fully investigate the feasibility of the integrated progress, our current research was carried out in a drinking water plant in Hunan province, located in central China $\left(\mathrm{N}: 27.7^{\circ}\right.$; E:111.2 ${ }^{\circ}$. Due to mining operations, the concentration of $\mathrm{Sb}$ is relatively high in the surface water, dominated by $\mathrm{Sb}(\mathrm{V})$. However, the traditional water treatment process cannot remove $\mathrm{Sb}(\mathrm{V})$ effectively in the local drinking water plant, resulting in high concentrations of $\mathrm{Sb}(\mathrm{V})$ in effluent. Here, the feasibility of the integrated progress was tested with the effluent as feed water. Some factors responsible for determining the antifouling properties of the integrated process were also investigated, such as the injection frequency, aeration rate, solution $\mathrm{pH}$, etc.

\section{Materials and methods}

\subsection{Characteristics of feed water}

The specific characteristics of the feed water (before upgrading) are listed in Table 1. Due to the dissolved oxygen in surface water, the main species of antimony in effluent was $\mathrm{Sb}(\mathrm{V})$, of which the proportion of concentration was as high as $99 \pm 1 \%$.

Table 1

The characteristics of feed water.

\begin{tabular}{ll}
\hline Parameters & Feed water \\
\hline Water temperature $\left({ }^{\circ} \mathrm{C}\right)$ & $27.2-29.8$ \\
$\mathrm{pH}$ & $7.3-7.9$ \\
Residual chlorine $(\mathrm{mg} / \mathrm{L})$ & $0.4-1.0$ \\
Turbidity $(\mathrm{NTU})$ & $0.3-1.0$ \\
Chromaticity & $1.0-7.0$ \\
Concentration of Sb $(\mu \mathrm{g} / \mathrm{L})$ & $5.4-19.8$ \\
Dissolved organic matter $(\mathrm{mg} / \mathrm{L})$ & $0.6-3.3$ \\
$\mathrm{UV}_{254}(1 / \mathrm{cm})$ & $0.01-0.013$ \\
\hline
\end{tabular}

\subsection{Preparation of flocs}

All chemical reagents used were analytical grade except when specified. Four commonly used coagulants $\left(\mathrm{AlCl}_{3} \cdot 6 \mathrm{H}_{2} \mathrm{O}\right.$, $\mathrm{Al}_{2}\left(\mathrm{SO}_{4}\right)_{3} \cdot 18 \mathrm{H}_{2} \mathrm{O}, \mathrm{FeCl}_{3} \cdot 6 \mathrm{H}_{2} \mathrm{O}$, and $\left.\mathrm{Fe}_{2}\left(\mathrm{SO}_{4}\right)_{3} \cdot \mathrm{xH}_{2} \mathrm{O}\right)$ were chosen in this study. The coagulants were dissolved into $400 \mathrm{~mL}$ deionized (DI) water each time and the corresponding flocs were prepared by adjusting the solution $\mathrm{pH}$ to 7.5 with $1 \mathrm{M} \mathrm{NaOH}$, which was similar to that of the feed water (pH 7.3-7.9). To prevent a high concentration of aluminum and iron in effluent after membrane filtration, the prepared flocs were washed by DI water three times before injecting. It was shown that almost $60 \%$ of aluminum species were solid hydrolysis products at $\mathrm{pH}$ 7.5 [25], while almost $100 \%$ of iron species were solid hydrolysis products [26]. Thus, the concentration of Al-based flocs was almost $60 \%$ of the concentration of Al-based coagulants, while the concentration of Fe-based flocs was almost equal to the concentration of Fe-based coagulants.

\subsection{Filtration progress}

A schematic illustration of the integrated membrane process is shown in Fig. S1. The height of the membrane tank was $800 \mathrm{~mm}$, and the inner diameter was $64 \mathrm{~mm}$. Feed water was fed into the UF membrane tank, comprising a polyvinylidene fluoride (PVDF) hollowfiber membrane module (Litree, China) with the average pore size of $30 \mathrm{~nm}$ (provided by the manufacturer). The effluent from the membrane module was continuously withdrawn by a peristaltic pump $(1 \mathrm{~L} /$ h), which was operated in a cycle of $30 \mathrm{~min}$ filtration and $1 \mathrm{~min}$ backwashing $(2 \mathrm{~L} / \mathrm{h})$. The water level was controlled by a water level gauge and a ceramic aeration device (diameter: $40 \mathrm{~mm}$ ) was set in the bottom of the membrane tank. The flocs were prepared before injecting each time to maintain the activity [27]. All flocs were suspended in the membrane tank with aeration from the bottom. The total concentration of flocs (calculated as $\mathrm{Al}$ or $\mathrm{Fe}$, the same below) was $50 \mathrm{mM}$ during the whole filtration (running for 10 days) and the flocs were directly injected into the membrane tank in batches (once every 2 days and once per day) or continuous injection with a peristaltic pump. The transmembrane pressure (TMP) was monitored by pressure sensors and recorded every day. The hydraulic retention time (HRT) was $2.2 \mathrm{~h}$ and the accumulated sludge was not released during the whole filtration. All samples were taken before the next injection, except in the continuous injection mode.

\subsection{Characteristics of flocs}

During the filtration at day 1, floc samples were taken from below the water surface to minimize impurities. Floc images were captured by a microscope with a CCD camera (GE-5, Aigo, China) after transferring the sample onto a microscope slide. The images were finally analyzed by Image $J$ software and the corresponding floc diameters were determined by the floc area. The average pore size of the pre-deposited membrane was also analyzed by Image $\mathrm{J}$ software [28]. The specific surface area of flocs was measured by the Brunauer-Emmett-Teller method (BET, ASAP2020HD88).

\subsection{Measurements of extracellular polymeric substances (EPS) in sludge}

The fouled membrane modules were carefully taken out from the membrane tank at the end of the experiment (day 10). A modified heating method was used to extract the EPS from the sludge [29]. The sludge suspension was first dewatered by centrifugation (Model 5417C, Eppendorf, Germany) in a tube $(50 \mathrm{~mL})$ at $4000 \mathrm{rpm}$ for $5 \mathrm{~min}$. The sludge pellet in the tube was re-suspended in phosphate buffer saline $(20 \mathrm{~mL})$ solution, sheared by a vortex mixer (Vortex-Genie 2, Mo Bio Laboratories, Inc, USA) for $10 \mathrm{~min}$, then treated by ultrasonication (Nusonics, USA) for $5 \mathrm{~min}$, and finally heated to $80{ }^{\circ} \mathrm{C}$ for another 
$30 \mathrm{~min}$. The mixture was centrifuged at $10,000 \mathrm{rpm}$ for $15 \mathrm{~min}$, and then the supernatant was used for EPS analysis.

A modification of the Bradford method was used to qualify the absolute concentrations of protein, using bovine serum albumin as the standard [30]. The absolute concentration of polysaccharide in EPS was measured by the phenol-sulfuric acid method, using glucose as the standard [31].

\subsection{Other analytical measurements}

Water temperature was obtained by a thermometer. $\mathrm{pH}$ was measured by an Orion benchtop $\mathrm{pH}$ meter. Water samples were filtered $(0.45 \mu \mathrm{m})$ and placed into a quartz cuvette to measure the UV absorbance at $254 \mathrm{~nm}$ using an ultraviolet/visible spectrophotometer (U-3010, Hitachi High Technologies Co., Japan). The total organic matter (TOC) was measured by the total organic matter analyzer (TOCVcph, SHIMADZU, Japan). Surface charges of flocs before and after adsorption were measured by a nano-particle sizing \& zeta potential analyzer (BECKMAN COULTER Ltd., USA). The antimony, aluminum and iron concentrations in effluent were measured by inductively coupled plasma mass spectrometry (ICP-MS, 7500a, Agilent Technology, USA). Images of the layered membrane surface were obtained using scanning electron microscopy (SEM, JSM-7401F, JEOL Ltd., Japan).

\section{Results}

\subsection{Effects of Al-based and Fe-based flocs}

To investigate the removal efficiency of $\mathrm{Sb}(\mathrm{V})$ and the effects of flocs on membrane behavior, the prepared flocs were injected into the membrane tank with the injection rate of once every 2 days (Fig. 1). The results showed that the removal efficiencies of $\mathrm{Sb}(\mathrm{V})$ were only $7.3 \%$ and $10.7 \%$ at day 2 and day 6 (before washing by feed water) without flocs. However, the removal efficiency of $\mathrm{Sb}(\mathrm{V})$ increased in the presence of flocs. In comparison with other flocs, flocs formed by $\mathrm{FeCl}_{3} \cdot 6 \mathrm{H}_{2} \mathrm{O}$ performed better, for which the removal efficiency of $\mathrm{Sb}(\mathrm{V})$ was as high as $40.7 \%$ after 10 days.

Fig. 1b shows that TMP significantly increased in the absence of flocs, and was $74.6 \mathrm{kPa}$ after running for 7 days with the higher water temperature (Table 1). At day 8, the TMP was dramatically reduced to $14.8 \mathrm{kPa}$ after washing with the feed water, indicating serious cake layer fouling. When flocs were suspended in the membrane tank, most particles could be removed/rejected by flocs during filtration. As a result, the corresponding TMP slowly increased. It was shown that Febased flocs also performed better in alleviating membrane fouling, especially with flocs formed by $\mathrm{FeCl}_{3} \cdot 6 \mathrm{H}_{2} \mathrm{O}$. The corresponding TMP

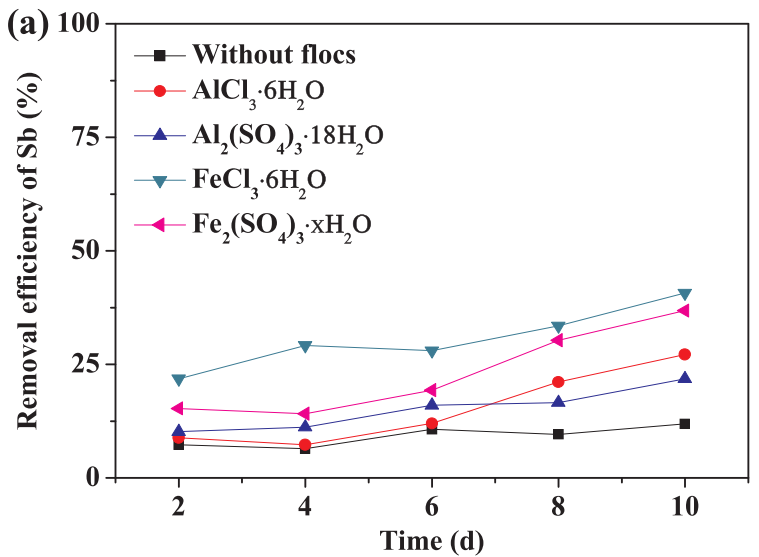

was $17.9 \mathrm{kPa}$ at day 10 , while it was $35.1 \mathrm{kPa}, 61.3 \mathrm{kPa}$ and $77.9 \mathrm{kPa}$ in the presence of flocs formed by $\mathrm{Fe}_{2}\left(\mathrm{SO}_{4}\right)_{3} \cdot \mathrm{xH}_{2} \mathrm{O}, \mathrm{AlCl}_{3} \cdot 6 \mathrm{H}_{2} \mathrm{O}$ and $\mathrm{Al}_{2}\left(\mathrm{SO}_{4}\right)_{3} \cdot 18 \mathrm{H}_{2} \mathrm{O}$, respectively.

\subsection{Effect of injection frequency}

It has been demonstrated that a high residual aluminum in drinking water may lead to some neurological problems, such as Alzheimer's disease [32,33]. Moreover, owing to the higher removal efficiency of Sb (V) and lower TMP development, flocs formed by $\mathrm{FeCl}_{3} \cdot 6 \mathrm{H}_{2} \mathrm{O}$ was further investigated (the same below). To investigate the behaviors of flocs, three different injection frequencies were chosen to understand the membrane performance (Fig. 2).

Fig. 2a shows that the removal efficiency of $\mathrm{Sb}(\mathrm{V})$ was higher with the continuous injection mode, being $53.6 \%$ at day 10 . This was higher than the value obtained with the injection rate of once every 2 days $(40.7 \%)$. However, more serious membrane fouling occurred when flocs were continuously injected into the membrane tank, so that TMP was $31.2 \mathrm{kPa}$ after 10 days. The corresponding TMP values were 26.8 $\mathrm{kPa}$ and $17.9 \mathrm{kPa}$ with the injection rates of once per day and once every 2 days, respectively.

\subsection{Effect of aeration rate}

The characteristics of flocs were significantly affected by aeration rate, such as the particle size, the attachment ability to the membrane surface, etc. It is well known that the larger the aeration rate, the smaller the particle size and the larger the specific surface area, which might influence the adsorption ability toward $\mathrm{Sb}(\mathrm{V})$. Furthermore, less affinity of flocs to the membrane surface was induced with larger aeration rate. Therefore, three different aeration rates $(0.1,0.2$ and $0.5 \mathrm{~L} / \mathrm{min}$ ) were investigated to understand the removal efficiency of $\mathrm{Sb}$ (V) and the TMP development (Fig. 3).

As seen from Fig. 3a, aeration rate had little effect on the removal efficiency of $\mathrm{Sb}(\mathrm{V})$. The removal efficiency of $\mathrm{Sb}(\mathrm{V})$ was $40.7 \%$ with the aeration rate of $0.1 \mathrm{~L} / \mathrm{min}$ and $37.3 \%$ with the higher aeration rate of $0.5 \mathrm{~L} / \mathrm{min}$. However, it was also clearly shown that lower TMP development occurred in the presence of a higher aeration rate, due to the smaller attachment ability of flocs to the membrane surface. After running for 10 days, the TMP increased to $17.9 \mathrm{kPa}$ when the aeration rate was $0.1 \mathrm{~L} / \mathrm{min}$, while increasing to $15.6 \mathrm{kPa}$ and $10.3 \mathrm{kPa}$ with the aeration rates of $0.2 \mathrm{~L} / \mathrm{min}$ and $0.5 \mathrm{~L} / \mathrm{min}$, respectively.

\subsection{Effect of solution $p H$}

Characteristics of flocs could also be dramatically influenced by solution $\mathrm{pH}$, especially the surface charge and the particle size. To

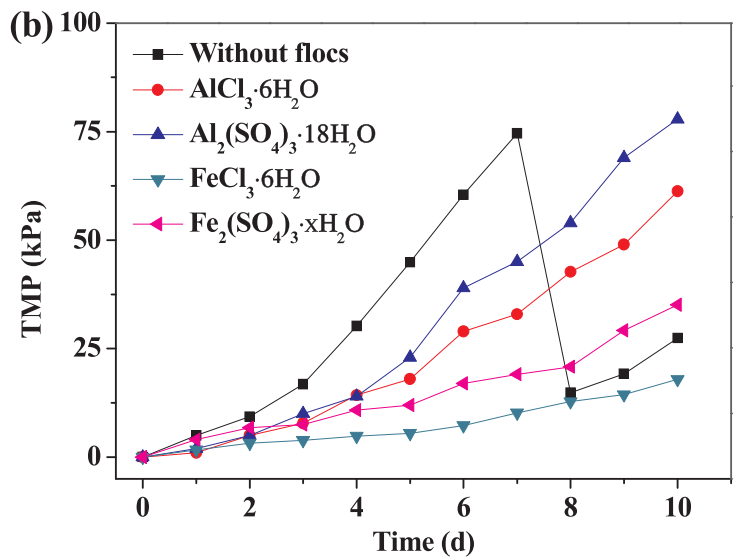

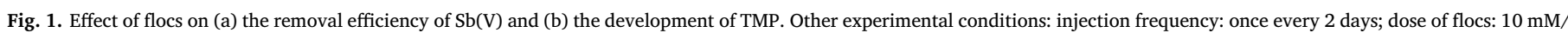
injection; water treatment capacity: $1 \mathrm{~L} / \mathrm{h}$; HRT: $2.2 \mathrm{~h}$; aeration rate: $0.1 \mathrm{~L} / \mathrm{min}$. 

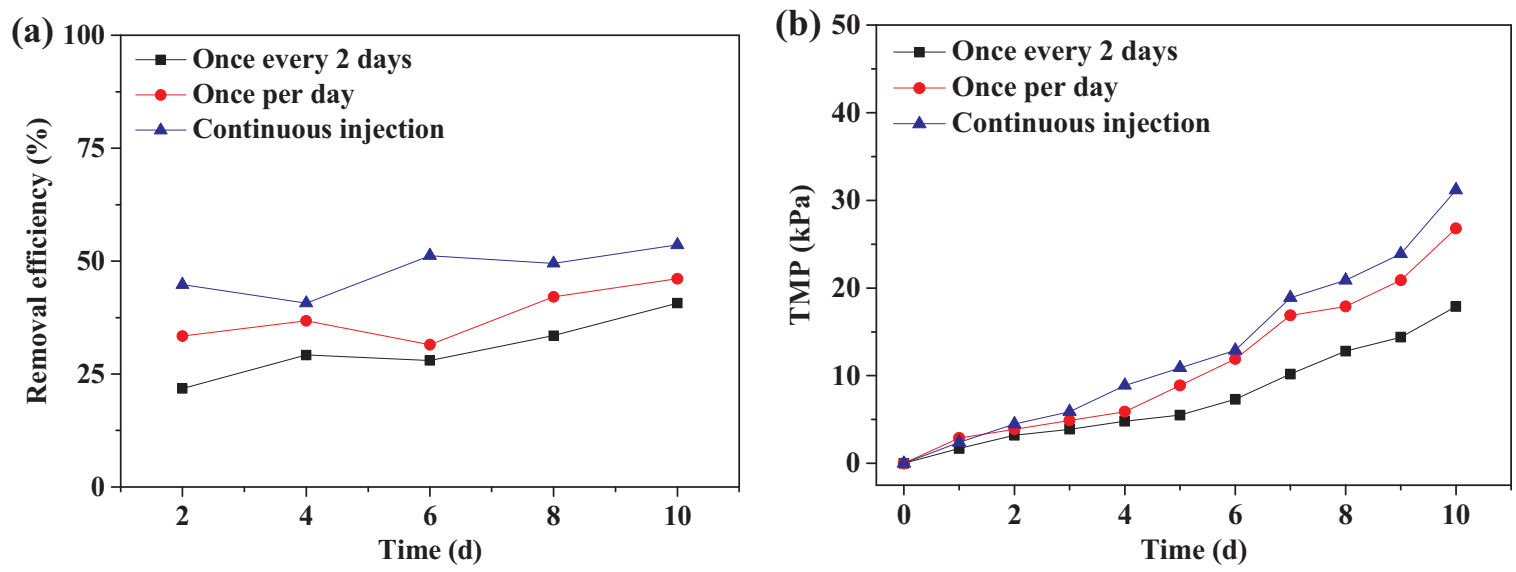

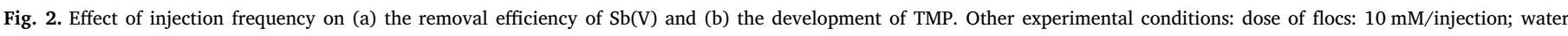
treatment capacity: $1 \mathrm{~L} / \mathrm{h}$; HRT: $2.2 \mathrm{~h}$; aeration rate: $0.1 \mathrm{~L} / \mathrm{min}$.

understand the membrane performance in the presence of Fe-based flocs, the removal efficiency of $\mathrm{Sb}(\mathrm{V})$ and the development of TMP were investigated under different $\mathrm{pH}$ conditions as shown in Fig. 4.

As seen from Fig. 4a, the removal efficiency of $\mathrm{Sb}(\mathrm{V})$ was as high as $92.8 \%$ at $\mathrm{pH} 6.0$ after running for 10 days, which was much higher than that at $\mathrm{pH} 9.0$ (only 15.9\%). Table S1 shows that the concentration of $\mathrm{Sb}(\mathrm{V})$ in effluent was lower than $1.0 \mu \mathrm{g} / \mathrm{L}$ at $\mathrm{pH}$ 6.0, which was significantly lower than the MCL of the United States, European Union, and China. In addition, the iron concentration in the effluent was almost the same (depending on the iron concentration of the influent: $0.02-0.08 \mathrm{mg} / \mathrm{L}$ ) before and after the membrane filtration, due to the larger particle size of flocs and the weakly acidic condition [26]. Fig. 4b shows that the TMP increased much more slowly at pH 6.0 than that $\mathrm{pH}$ 9.0. The TMP at $\mathrm{pH} 6.0$ was only $3.7 \mathrm{kPa}$ after running for 10 days. However, the development of TMP increased with rising solution $\mathrm{pH}$. The corresponding TMP values were $17.9 \mathrm{kPa}$ and $22.3 \mathrm{kPa}$ at $\mathrm{pH} 7.5$ and $\mathrm{pH} 9.0$ at day 10 , respectively.

\section{Discussion}

Owing to the high water temperature (Table 1), microorganisms easily proliferated in the membrane tank without disinfection (Fig. S2). Thus, the morphology of the membrane surface was investigated in the absence/presence of flocs before and after filtration (Fig. 5). In contrast with the virgin membrane surface (Fig. 5a), it is clearly shown that a dense cake layer was formed by EPS in the absence of flocs after running for 7 days (Fig. 5b).

For the removal of $\mathrm{Sb}(\mathrm{V})$, although $\mathrm{Sb}(\mathrm{V})$ could be adsorbed by

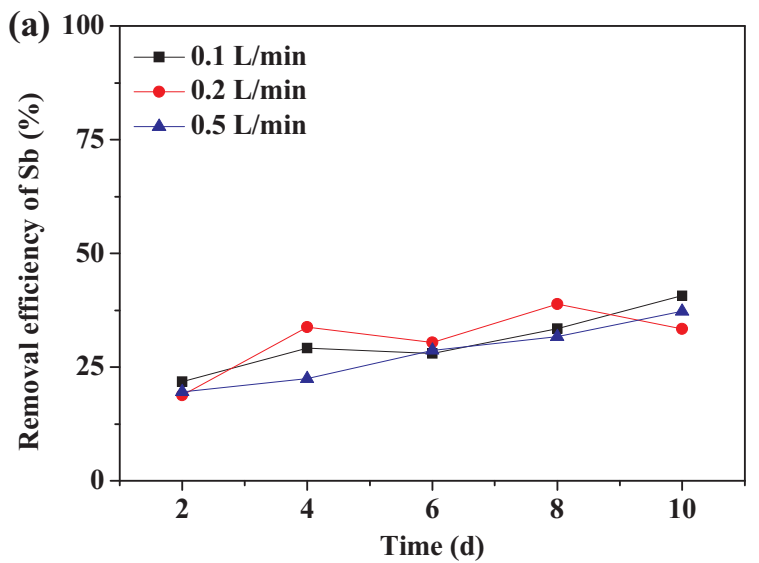

membrane pores during filtration [9], the removal efficiency is low because of the relatively large pore diameter (average pore diameter: $30 \mathrm{~nm})$. Fig. 1a shows that the removal efficiency of $\mathrm{Sb}(\mathrm{V})$ by the UF membrane alone was $7.3 \%$ at day 2 , while rising to $10.7 \%$ at day 6 . This meant that both the UF membrane and the corresponding EPS could not remove $\mathrm{Sb}(\mathrm{V})$ effectively. However, the removal efficiency of $\mathrm{Sb}(\mathrm{V})$ was higher when injecting flocs, being $27.2 \%$ and $40.7 \%$ in the presence of flocs formed by $\mathrm{AlCl}_{3} \cdot 6 \mathrm{H}_{2} \mathrm{O}$ and $\mathrm{FeCl}_{3} \cdot 6 \mathrm{H}_{2} \mathrm{O}$ at day 10, respectively. This was consistent with the previous studies, which have demonstrated that iron salts had a strong adsorption ability toward $\mathrm{Sb}(\mathrm{V})$ due to the formation of an inner-sphere complex [23]. With increasing concentration of flocs, the removal efficiency of $\mathrm{Sb}(\mathrm{V})$ slowly increased (Fig. 1a).

Previous studies have reported that EPS always cause severe membrane fouling due to the dense cake layer formed [34-37]. Therefore, the TMP significantly increased to $74.6 \mathrm{kPa}$ at day 7 in the absence of flocs. However, the TMP was dramatically reduced to 14.8 $\mathrm{kPa}$ at day 8 by washing the membrane surface carefully with feed water, indicating that cake layer formation was the main fouling mechanism. When the loose flocs were injected, they were well dispersed and in the membrane tank, and were also easily attached to the membrane surface during filtration. As a result, most EPS was wrapped into the flocs first (Fig. 5c), reducing the possibilities getting to the membrane surface directly and alleviating membrane fouling dramatically.

To further understand the variation of TMP, the concentrations of protein and polysaccharide in the sludge were investigated at day 10 in detail (Fig. 6). The results showed that the concentration of protein or polysaccharide was lower in the presence of Fe-based flocs compared

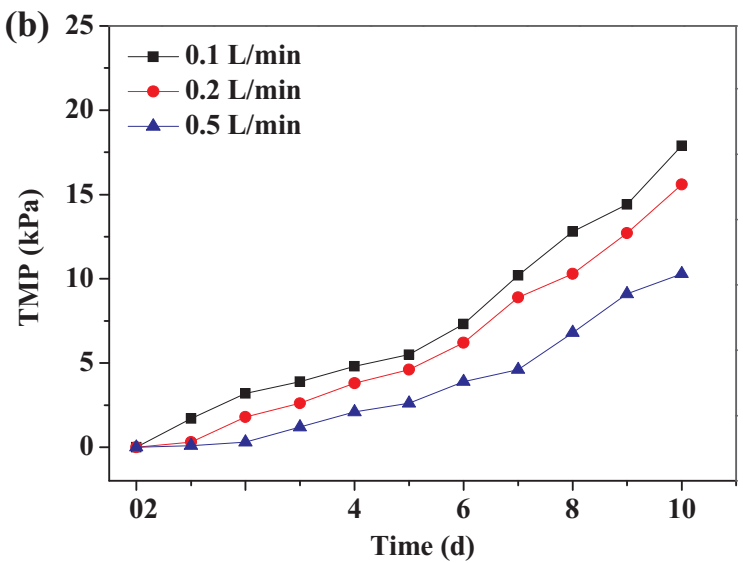

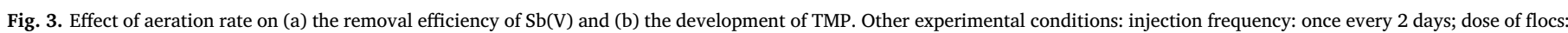
$10 \mathrm{mM}$ /injection; water treatment capacity: $1 \mathrm{~L} / \mathrm{h}$; HRT: $2.2 \mathrm{~h}$. 

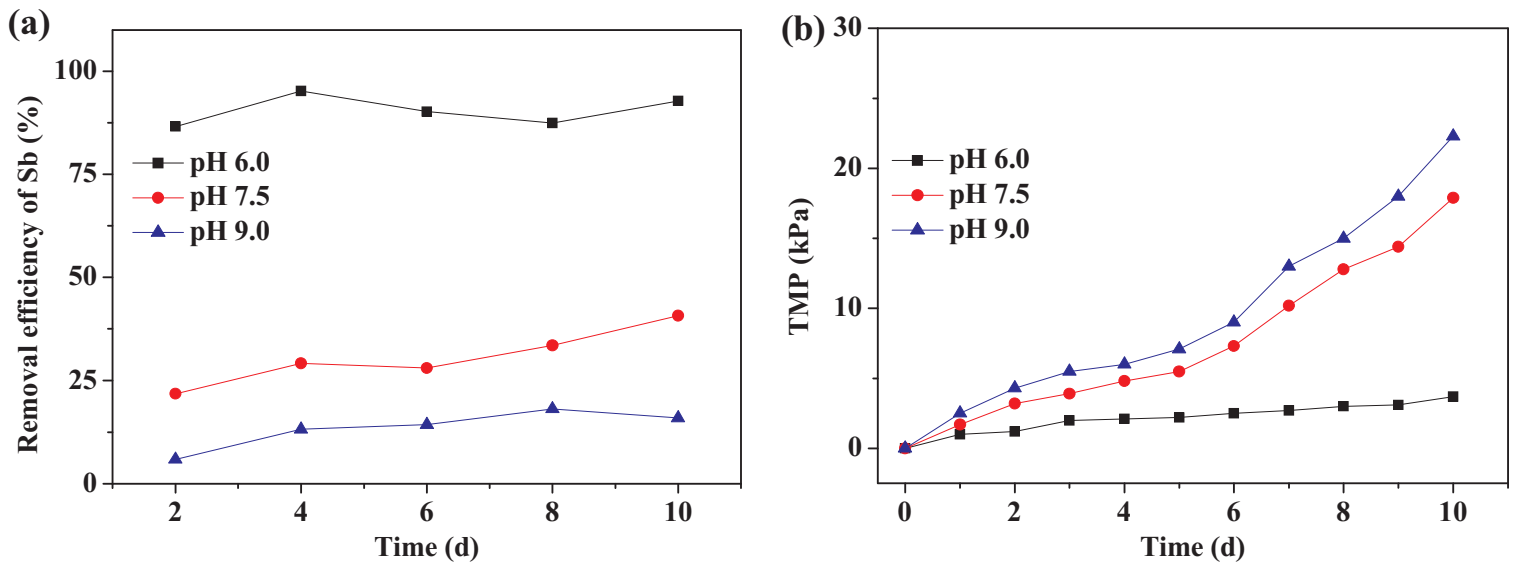

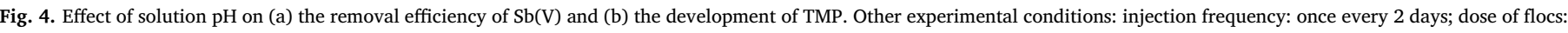
$10 \mathrm{mM} /$ injection; water treatment capacity: $1 \mathrm{~L} / \mathrm{h}$; HRT: $2.2 \mathrm{~h}$; aeration rate: $0.1 \mathrm{~L} / \mathrm{min}$.

with the Al-based flocs. A possible reason was that microorganisms did not easily proliferate in the presence of the corrosive Fe-based flocs [38]. Thus, the membrane fouling was more severe with suspended Albased flocs (Fig. 1b). In addition, the concentration of protein was much higher than that of polysaccharide, indicating that the major components of EPS were protein-like substances.

When Fe-based flocs were directly injected into the membrane tank with the frequency of once every 2 days, most adsorption sites of flocs could not be fully utilized owing to the presence of sludge. Moreover, the characteristics of flocs gradually became inactive as a function of time [27]. Thus, the removal efficiency of $\mathrm{Sb}(\mathrm{V})$ was only $40.7 \%$, and $53.6 \%$ with the continuous injection. In addition, the inhibition of microorganism development was greater with the injection mode of once every 2 days due to the stronger corrosive properties [38]. The total concentrations of protein and polysaccharide were $16.7 \pm 1.4 \mu \mathrm{g} /$ $\mathrm{g}$ (injection every 2 days) and $19.8 \pm 2.1 \mu \mathrm{g} / \mathrm{g}$ with the continuous injection. As a result, membrane fouling was relatively severe with the continuous injection (Fig. 2b).
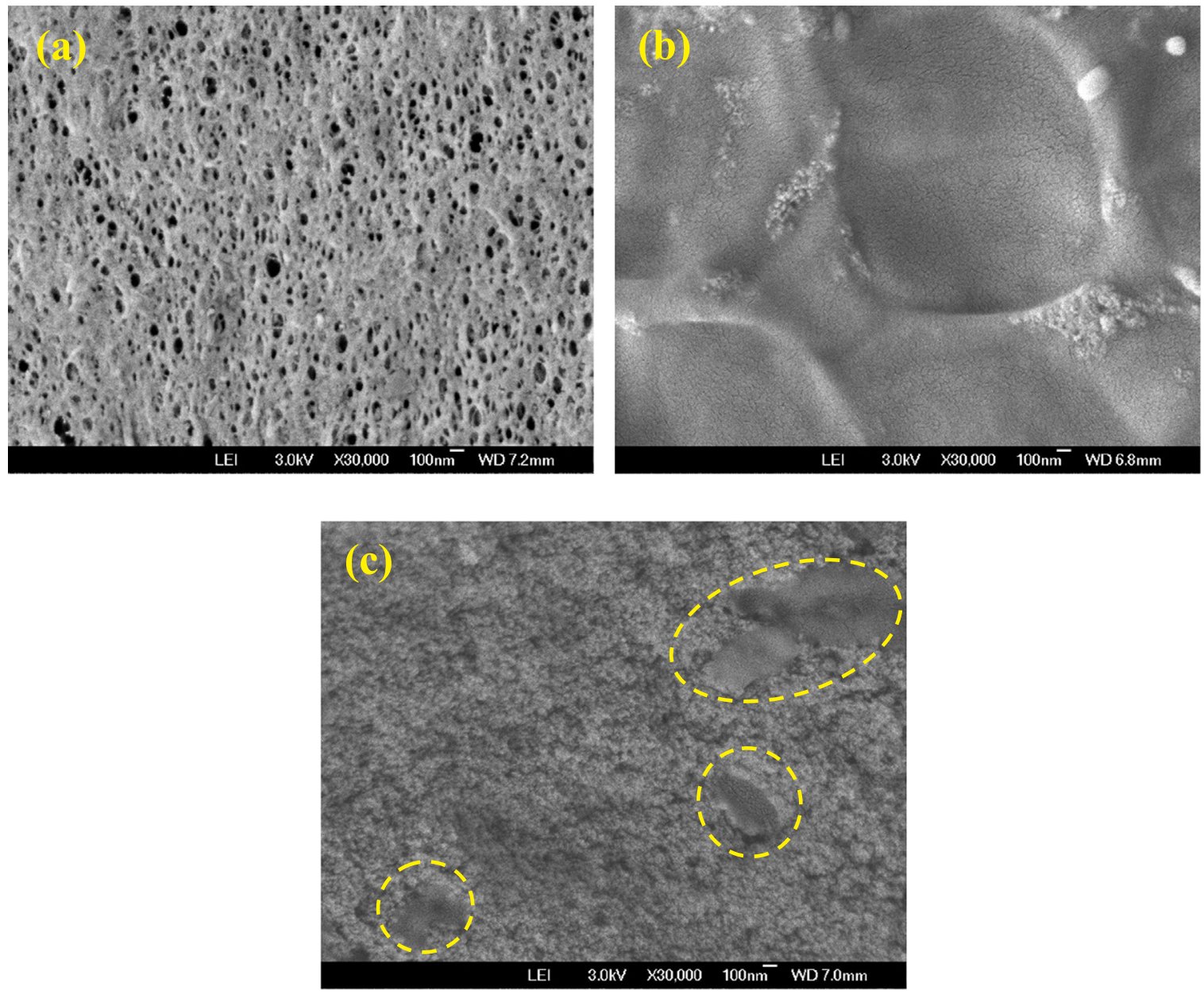

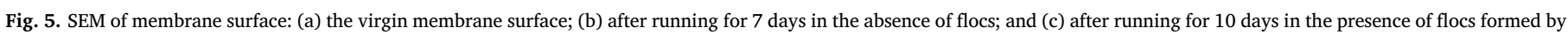

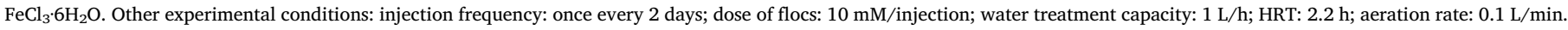



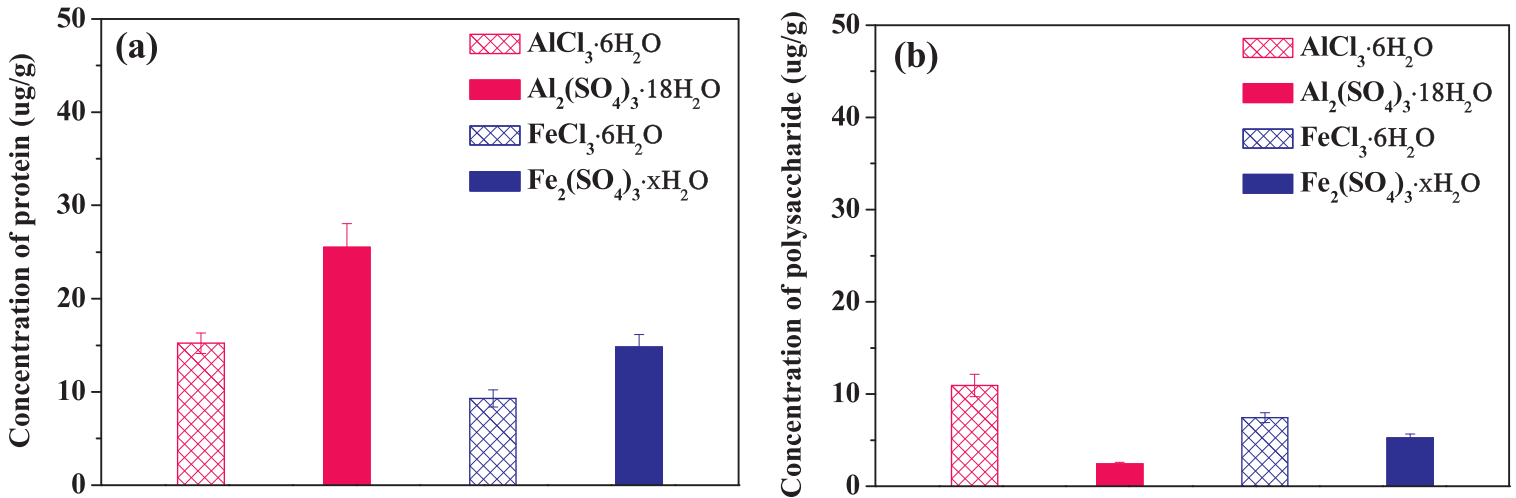

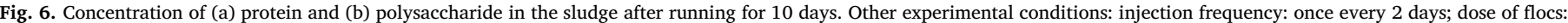
$10 \mathrm{mM} /$ injection; water treatment capacity: $1 \mathrm{~L} / \mathrm{h}$; HRT: $2.2 \mathrm{~h}$; aeration rate: $0.1 \mathrm{~L} / \mathrm{min}$.
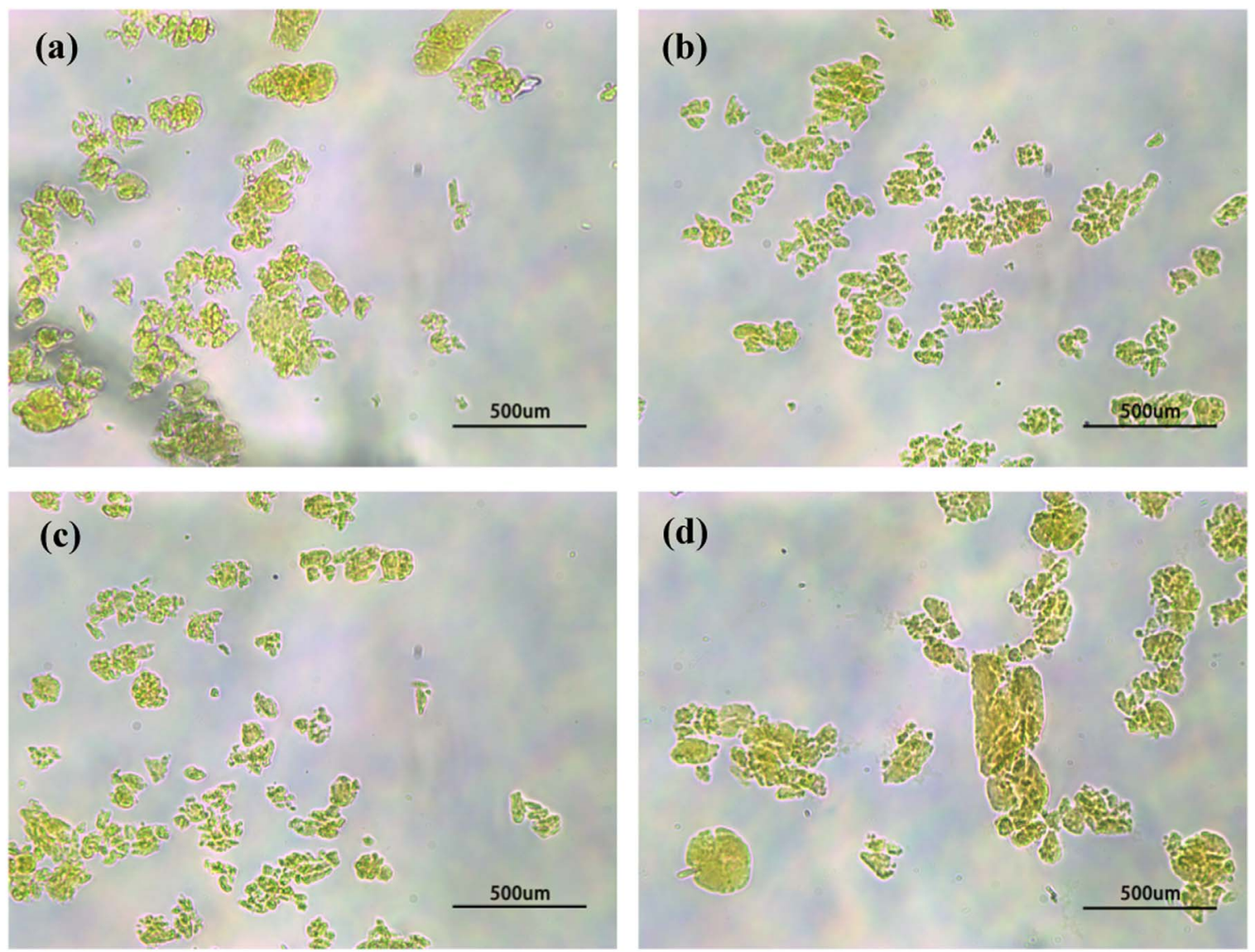

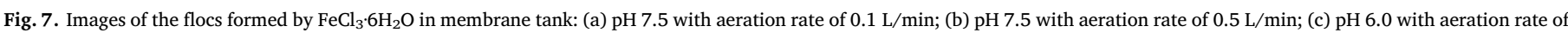

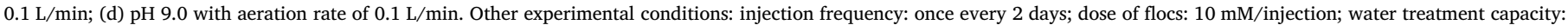
$1 \mathrm{~L} / \mathrm{h}$; HRT: $2.2 \mathrm{~h}$.

The integrated UF membrane process was also influenced by the aeration rate to some extent (Fig. 3). The images in Fig. 7a and b show the floc sizes at different aeration rates. The average particle size was $273.3 \pm 14.8 \mu \mathrm{m}$ with the aeration rate of $0.1 \mathrm{~L} / \mathrm{min}$, while it was $219.5 \pm 21.6 \mu \mathrm{m}$ with the aeration rate of $0.5 \mathrm{~L} / \mathrm{min}$. Although the specific surface area of flocs produced with the aeration rate of $0.5 \mathrm{~L} /$ $\min \left(312.1 \pm 9.7 \mathrm{~m}^{2} / \mathrm{g}\right)$ was larger than that with the aeration rate of $0.1 \mathrm{~L} / \mathrm{min}\left(288.6 \pm 13.4 \mathrm{~m}^{2} / \mathrm{g}\right)$, the removal efficiency of $\mathrm{Sb}(\mathrm{V})$ was influenced little by aeration rate. The main reason was that the electrostatic attraction effect between Fe-based flocs and $\mathrm{Sb}(\mathrm{V})$ played an important role $[1,23]$, while the zeta potentials of Fe-based flocs varied little (data not shown) with changes in aeration rate. In addition, the electrostatic attraction force between $\mathrm{Sb}(\mathrm{V})$ and Fe-based flocs was much stronger than the shearing force induced by aeration, even with the aeration rate of $0.5 \mathrm{~L} / \mathrm{min}$. Thus, the removal efficiency of $\mathrm{Sb}(\mathrm{V})$ was influenced little by aeration rate. Furthermore, the total concentrations of protein and polysaccharide were almost the same (about $16.7 \pm 1.4 \mu \mathrm{g} / \mathrm{g}$ ) with different aeration rates, and greater aeration rate resulted in flocs with less attachment ability. Accordingly, the corresponding TMP was $17.9 \mathrm{kPa}$ when the aeration rate was $0.1 \mathrm{~L} / \mathrm{min}$, while it was $10.3 \mathrm{kPa}$ when the aeration rate was $0.5 \mathrm{~L} / \mathrm{min}$ at day 10 .

Solution $\mathrm{pH}$ was another important factor in the performance of flocs. The zeta potential of flocs formed by $\mathrm{FeCl}_{3} \cdot 6 \mathrm{H}_{2} \mathrm{O}$ was $9.7 \pm 2.1 \mathrm{mV}$ at $\mathrm{pH} 6.0$, while the values were $2.5 \pm 0.8 \mathrm{mV}$ at $\mathrm{pH}$ 7.5, and $-3.1 \pm 0.9 \mathrm{mV}$ at $\mathrm{pH} 9.0$, respectively. It is known that $\mathrm{Sb}(\mathrm{V})$ is negatively charged $\left(\mathrm{Sb}(\mathrm{OH})_{6}{ }^{-}\right)$between $\mathrm{pH} \mathrm{3-10}[4,5]$, so that it is 
easily adsorbed by the positively charged Fe-based flocs under lower $\mathrm{pH}$ conditions. Fig. $7 c$ and $7 d$ show the images of the flocs formed by $\mathrm{FeCl}_{3} \cdot 6 \mathrm{H}_{2} \mathrm{O}$ under different $\mathrm{pH}$ conditions, illustrating that the average particle size was $114.1 \pm 9.2 \mu \mathrm{m}$ at $\mathrm{pH} 6.0$, and $306.7 \pm 22.4 \mu \mathrm{m}$ at $\mathrm{pH}$ 9.0. Smaller particles have larger specific surface area. The specific surface areas were $337.9 \pm 10.3 \mathrm{~m}^{2} / \mathrm{g}$ at $\mathrm{pH} 6.0$, and $276.3 \pm 18.4 \mathrm{~m}^{2} /$ $\mathrm{g}$ at $\mathrm{pH}$ 9.0. In fact, the average pore diameter of the floc cake layer analyzed by Image $J$ software was $4.8 \pm 0.3 \mathrm{~nm}(\mathrm{pH} 6.0)$ and $5.6 \pm 0.7 \mathrm{~nm}(\mathrm{pH} 9.0)$, as shown in Fig. S3. For the aforementioned reasons, much higher removal efficiency occurred at $\mathrm{pH}$ 6.0. This was also consistent with a previous study, which reported that the variation of $\mathrm{Sb}$ removal efficiency varied significantly as a function of solution $\mathrm{pH}$ in the presence of ferric hydroxide [4].

Furthermore, the activity of microorganisms would be inhibited under acidic conditions [39]. In comparison with the total concentration of protein and polysaccharide $(16.7 \pm 1.4 \mu \mathrm{g} / \mathrm{g})$ at $\mathrm{pH} 7.5$, the total concentration of protein and polysaccharide was only $9.4 \pm 0.5 \mu \mathrm{g} / \mathrm{g}$ at $\mathrm{pH}$ 6.0. As a result, lower development of TMP occurred (Fig. 4b). Owing to the weakly acidic conditions, the concentration of iron and chromaticity in the effluent were almost unchanged before and after the filtration. Although the activity of microorganisms would also be inhibited under alkaline conditions (the total concentration of protein and polysaccharide was $12.6 \pm 1.8 \mu \mathrm{g} / \mathrm{g}$ at $\mathrm{pH}$ 9.0), the floc particle size was larger and the specific surface area was smaller, leading to worse membrane performance (Fig. 4b).

In view of the foregoing observations, the process combining flocs and UF membrane behaved well, especially in the presence of Fe-based flocs. Continuous injection performed better in the removal efficiency of $\mathrm{Sb}(\mathrm{V})$, while a little worse in alleviating membrane fouling. However, the aeration rate had little effect on the removal efficiency of $\mathrm{Sb}(\mathrm{V})$, while playing an important role in the development of TMP. Both $\mathrm{Sb}(\mathrm{V})$ removal efficiency and TMP development were better under acidic conditions. Further research will be focused on the long-time filtration properties with different sludge discharge frequencies and in situ chemical cleaning with disinfection.

\section{Conclusions}

Inspired by the favorable characteristics of in situ flocs and UF membrane, we developed a novel process for $\mathrm{Sb}(\mathrm{V})$ removal. We found that the in situ flocs could be well suspended in the membrane tank with aeration from the bottom, and could thus be fully utilized. The integrated membrane process performed better in removing $\mathrm{Sb}(\mathrm{V})$ and less severe membrane fouling was induced, especially with Fe-based flocs. Continuous injection has great potential for removing $\mathrm{Sb}(\mathrm{V})$ owing to the freshness of the flocs. Aeration rate had little effect on the removal efficiency of $\mathrm{Sb}(\mathrm{V})$, while playing an important role in reducing membrane fouling, especially for the highest aeration rate.

Moreover, Fe-based flocs had higher positive charge and larger specific surface area under acidic conditions, resulting in stronger adsorption/rejection ability toward $\mathrm{Sb}(\mathrm{V})$. The activity of microorganisms was also inhibited, leading to alleviation of the development of TMP during filtration. In addition, the introduction of Fe-based flocs had little effect on the iron concentration, turbidity and chromaticity in the effluent.

Specifically, this study highlights the advantages of in situ flocs combined with an UF membrane in removing $\mathrm{Sb}(\mathrm{V})$, including stronger adsorption ability, lower cost and better rejection efficiency than other comparable techniques. This innovative separation method, initially developed for separation of $\mathrm{Sb}(\mathrm{V})$ in aqueous solution, has potential for broader applications in water treatment.

\section{Acknowledgements}

This study was supported by a major program granted by the National Natural Science Foundation of China (51290282). This work was also supported by the National Natural Science Foundation for Young Scientists of China (51608514).

\section{Appendix A. Supporting information}

Supplementary data associated with this article can be found in the online version at http://dx.doi.org/10.1016/j.memsci.2017.05.022.

\section{References}

[1] Z. He, R.P. Liu, H.J. Liu, J.H. Qu, Adsorption of Sb(III) and Sb(V) on freshly prepared Ferric Hydroxide (FeOxHy), Environ. Eng. Sci. 32 (2015) 95-102.

[2] S.Y. Nishiyama, K. Saito, K. Sugita, K. Sato, M. Akiba, T. Saito, S. Tsuneda, A. Hirata, M. Tamada, T. Sugo, High-speed recovery of antimony using chelaing porous hollow fiber membrane, J. Membr. Sci. 214 (2003) 275-281.

[3] M. Filella, P.M. May, Critical appraisal of available thermodynamic data for the complexation of antimony(III) and antimony(V) by low molecular mass organic ligands, J. Environ. Monit. 7 (2005) 1226-1237.

[4] M. Filella, N. Belzile, Y. Chen, Antimony in the environment: a review focused on natural waters I. Occurrence, Earth Sci. Rev. 57 (2002) 125-176.

[5] M. Filella, N. Belzile, Y. Chen, Antimony in the environment: a review focused on natural water II. Relevant solution chemistry, Earth Sci. Rev. 59 (2002) 265-285.

[6] W. Xu, H.J. Wang, R.P. Liu, X. Zhao, J.H. Qu, The mechanism of antimony(III) removal and its reactions on the surfaces of Fe-Mn binary oxide, J. Colloid Interface Sci. 363 (2011) 320-326.

[7] X.J. Guo, Z.J. Wu, M.C. He, Removal of antimony(V) and antimony(III) from drinking water by coagulation-flocculation-sedimentation (CFS), Water Res. 43 (2009) 4327-4335.

[8] Z.J. Wu, M.C. He, X.J. Guo, R.J. Zhou, Removal of antimony(III) and antimony(V) form drinking water by ferric chloride coagulation; competing ion effect and the mechanism analysis, Sep. Purif. Technol. 76 (2010) 184-190.

[9] S.Y. Nishiyama, K. Saito, K. Sugita, K. Sato, M. Akiba, T. Saito, S. Tsuneda, A. Hirata, M. Tamada, T. Sugo, High-speed recovery of antimony using chelating porous hollow-fiber membrane, J. Membr. Sci. 214 (2003) 275-281.

[10] A.S. Koparal, R. Ozgur, U.B. Ogutveren, H. Bergmann, Antimony removal from model acid solutions by electrodeposition, Sep. Purif. Technol. 37 (2004) 107-116.

[11] X.Q. Zhao, X.M. Dou, D. Mohan, C.U. Pittman, Y.S. Ok, X. Jin, Antimonate and antimonite adsorption by a polyvinyl alcohol-stabilized granular adsorbent containing nanoscale zero-valent iron, Chem. Eng. J. 247 (2014) 250-257.

[12] B.K. Biswas, J. Inoue, H. Kawakita, K. Ohto, K. Inoue, Effective removal and recovery of antimony using metal-loaded saponified orange waste, J. Hazard. Mater. 172 (2009) 721-728.

[13] C. Shan, Z.Y. Ma, M.P. Tong, Efficient of removal of trace antimony(III) through adsorption by hematite modified magnetic nanoparticles, J. Hazard. Mater. 268 (2014) 229-236.

[14] G. Ungureanu, S. Santos, R. Boaventura, C. Botelho, Arsenic and antimony in water and wastewater: overview of removal techniques with special reference to latest advances in adsorption, J. Environ. Manag. 151 (2015) 326-342.

[15] A. Sari, D. Citak, M. Tuzen, Equilibrium, thermodynamic and kinetic studies on adsorption of $\mathrm{Sb}(\mathrm{III})$ from aqueous solution using low cost natural diatomite, Chem. Eng. J. 162 (2010) 521-527.

[16] M. Iqbal, A. Saeed, R.G.J. Edyvean, Bioremoval of antimony(III) from contaminated water using several plant wastes: optimization of batch and dynamic flow conditions for sorption by green bean husk (Vigna radiata), Chem. Eng. J. 225 (2013) 192-201.

[17] R.P. Liu, W.X. Gong, H.C. Lan, Y.P. Gao, H.J. Liu, J.H. Qu, Defluoridation by freshly prepared aluminum hydroxides, Chem. Eng. J. 175 (2011) 144-149.

[18] J. Citulski, K. Farahbakhsh, F. Kent, H.D. Zhou, The impact of in-line coagulant addition on fouling potential of secondary effluent at a pilot-scale immersed ultrafiltration plant, J. Membr. Sci. 325 (2008) 311-318.

[19] H. Guo, Y. Wyar, J. Perot, F. Naulear, P. Moulin, Low-pressure membrane for integrity tests for drinking water treatment: a review, Water Res. 44 (2010) 41-57.

[20] B.W. Ma, C.Z. Hu, X. Wang, Y.R.W. Xie, W.A. Jefferson, H.J. Liu, J.H. Qu, Effect of aluminum speciation on ultrafiltration membrane fouling by low dose aluminum coagulation with bovine serum albumin (BSA), J. Membr. Sci. 492 (2015) 88-94.

[21] C. Conidi, R. Mazzei, A. Cassano, L. Giorno, Integrated membrane systems for the production of phytotherapics from olive mill wastewaters, J. Membr. Sci. 454 (2014) 322-329.

[22] M. Kang, T. Kamei, Y. Magara, Comparing polyaluminum chloride and ferric chloride for antimony removal, Water Res. 37 (2013) 4171-4179.

[23] A.K. Leuz, H. MÖnch, C.A. Johnson, Sorption of Sb(III) and Sb(V) to goethite: influence on Sb(III) oxidation and mobilization, Environ. Sci. Technol. 40 (2006) 7277-7282.

[24] G. Okkenhaug, G.D. Breedveld, T. Kirkeng, M. Laegreid, T. Maehlum, J. Mulder, Treatment of air pollution control residues with iron rich waste sulfuric acid: does i work for antimony (Sb), J. Hazard. Mater. 248 (2013) 159-166.

[25] H. Zhao, H.J. Liu, C.Z. Hu, J.H. Qu, Effect of aluminum speciation and structure characterization on preferential removal of disinfection byproduct precursors by aluminum hydroxide coagulation, Environ. Sci. Technol. 43 (2009) 5067-5072.

[26] W.J. Eilbeck, G. Mattack, Chemical progresses in wastewater treatment, John-Wiley and Sons, West Sussex (1987).

[27] X.D. Chen, H.W. Yang, W.J. Liu, X.M. Wang, Y.F. Xie, Filterability and structure of the fouling layers of biopolymer coexisting with ferric iron in ultrafiltration 
membrane, J. Membr. Sci. 495 (2015) 81-90.

[28] G.S. Ajmani, D. Goodwin, K. Marsh, D.H. Fairbrother, K.J. Schwab, J.G. Jacangelo, H.O. Huang, Modification of low pressure membranes with carbon nanotube layers for fouling control, Water Res. 46 (2012) 5645-5654.

[29] J.W. Morgan, C.F. Forster, L. Evison, A comparative study of the nature of biopolymers extracted from anaerobic and activated sludge, Water Res. 24 (1990) 743-750.

[30] G. Peterson, A simplification of the protein assay method of Lowry et al. which is more generally applicable, Anal. Biochem. 83 (1977) 346-356.

[31] M. Dubios, K.A. Gilles, J.K. Hamilton, P.A. Rebers, F. Smith, Colorimetric method for determination of sugars and related substances, Anal. Chem. 28 (1956) 350-356.

[32] Z.L. Yang, B.Y. Gao, W.Y. Xu, B.C. Cao, Q.Y. Yue, Effect of $\mathrm{OH}^{-} / \mathrm{Al}^{3+}$ and $\mathrm{Si} / \mathrm{Al}$ molar ratios on the coagulation performance and residual $\mathrm{Al}$ speciation during surface water treatment with poly-aluminum-silicate-chloride (PASiC), J. Hazard. Mater. 189 (2011) 203-210.

[33] E. Gauthier, I. Fortier, F. Courchesne, P. Pepin, J. Mortimer, D. Gauvreau, Aluminum forms in drinking water and risks of Alzheimer's disease, Environ. Res. 84 (2000) 234-246.
[34] A. Cosenza, G.D. Bella, G. Mannina, M. Torregrossa, The role of EPS in fouling and foaming phenomena for a membrane reactor, Bioresour. Technol. 147 (2013) 184-192.

[35] R.H. Peiris, M. Jaklewicz, H. Budman, R.L. Legge, C. Moresoli, Assessing the role of feed water constituents in irreversible membrane fouling of pilot-scale ultrafiltration drinking water treatment systems, Water Res. 47 (2013) 3364-3374.

[36] W.Z. Yu, N.J.D. Graham, G.D. Fowler, Coagulation and oxidation for controlling ultrafiltration membrane fouling in drinking water treatment: application of ozone at low dose in submerged membrane tank, Water Res. 95 (2016) 1-10.

[37] S. Ibeid, M. Elektorowicz, J.A. Oleszkiewicz, Electro-conditioning of activated sludge in a membrane electro-bioreactor for improved dewatering and reduced membrane fouling, J. Membr. Sci. 494 (2015) 136-142.

[38] X.L. Zhao, Y.J. Zhang, Algae-removing and algicidal efficiencies of polydiallyldimethylammonium chloride composite coagulants in enhanced coagulation treatment of algae-containing raw water, Chem. Eng. J. 173 (2011) 164-170.

[39] M.H. Hwang, N.J. Jang, S.H. Hyun, I.S. Kim, Anaerobic bio-hydrogen production from ethanol fermentation: the role of pH, J. Biotechnol. 111 (2004) (2004) 297-309. 